\title{
HOSPITAL AND TRAINING-SCHOOL ITEMS
}

\author{
IN CHLBOE OF \\ LINDA RICHARDS
}

As a diversion to their more arduous task of attending the sick, the nurses of the Presbyterian Hospital, Philadelphia, have constituted themselves into a fire brigade and are taking regular lessons in the art of extinguishing flames. The cause of their sudden enthusiastic activity in this direction was a recent order promulgated by the Board of Directors of the hospital to the effect that every employee in the building be initiated into the secret of handling the fire-hose. By the many nurses the order was regarded as a sort of respite from their usual duties, and was immediately hailed with unconcealed delight. For many years the question of equipping the hospital with hose and other fire paraphernalia has engrossed the attention of the directors at their monthly meetings. Continual agitation finally had the desired effect, and now the whole building is thoroughly equipped with fire-fighting devices of all descriptions.

The male employees of the hospital are quartered on the fifth floor of the building, and in case of fire they will be aroused by Night Superintendent Linton, who is situated near a large brass gong. The men seem imbued with a practical view of the new system, and go through their drills without displaying any interest whatever or admitting that the thing is a novelty.

The nurses, however, derive all sorts of pleasure from the drill, and while all shudder at the thought of a fire, they promise to do their duty. when occasion requires.

The Manhattan Maternity Hospital and Dispensary, New York City, is a gift to the poor of the East Side from a man who has long been interested in the question of the betterment of East-Side conditions. He has not only given the money to purchase the site and erect the buildings, but he has also endowed the hospital to such an extent that it will be entirely independent of other contributions.

Several possible sites for the new hospital are under consideration, but the one that will probably be selected is near Seventieth Strect and First Avenue. In fact, negotiations for property in that neighborhood are now going on. As soon as the site has been selected the plans for the 
buildings will be drawn and the work of putting up the hospital will begin. It is hoped to begin the work within a month and have the hospital ready for use by next year.

The buildings will occupy almost an entire block, and will include, besides a hospital, a dispensary and a training-school for nurses. The hospital will be equipped with all the most modern appliances, and will have a large corps of doctors and nurses, with accommodations for them. Most of the beds will be free, but there will be a limited number of paid beds also.

The Union Hospital, of Lynn, Massachusetts, has bought the Tapley estate in Linwood Road, that city, consisting of a house containing twenty rooms, and a lot of land with an area of twenty-five thousand square feet.

The building is in condition for immediate occupancy, but some improvements will be made before patients are received in order to make the hospital attractive and pleasant. Forty patients can be cared for in the several private rooms and the two large wards. Several individuals have promised to donate one bed each, with all the furnishings complete, ready to reccive a patient, for the privilege of naming the bed in the memory of some relative or friend. Several fraternal bodies have agreed to pay a certain sum annually to maintain a bed which shall be frce to members of their ordcr. A lay board of management is provided for by the articles of incorporation. This will consist of twelve men and twelve women, to be selected from the representative people of the city.

By the will of Stephen Symmes, of Arlington, Massachusetts, which was offered for probate March 15 at the Middlesex Registry of Probate, the bulk of the property, amounting to about twenty-five thousand dollars, is left to found a hospital and nurses'training-school in Arlington.

The Symmes place, two and a half acres of high land with a house and farm buildings, is an ideal location for a hospital. It is about a mile from the centre of Arlington, on old Mystic Street, just off the road to Winchester. Though only a few minutes' walk from the electric cars, it is well sheltered from the travelled highway. The house overlooks the beautiful chain of Mystic lakes, with the valley parkway and the ancient Brooks estate on the other side.

The testator furthermore requests that the name Symmes, or Stephen Symmes, shall be a part of the designation of the hospital.

The Medical College and Dispensary building of the Bellevue Hospital group, New York City, is to be changed into a maternity hospital, dispensary, and dormitory. The changes, which will be made to the 
interior of the building, have been estimated to cost twenty thousand dollars. The object of this change is to bring all departments of the hospital within the Bellevue yard at East Twenty-sixth Street. At present maternity cases are cared for in a building rented by the city on Twenty-sixth Street between Second and Third Arenues. Besides involving an extra expense for rent, this causes some trouble to the hospital staff, as these wards are a block and a half away from the main hospital.

Strong influence is being brought to bear on the Legislature of New Jersey for the passage of the pending bill to appropriate fifty thousand dollars for the construction of a State hospital for the treatment of consumption. At a hearing before the Executive Committee Dr. Flick, of Philadelphia, said that in Germany, Massachusetts, and New York it has been proven that in government sanatoriums forty per cent. or more of the cases of tuberculosis were curable. Consumption now causes one hundred thousand deaths a year in the United States. With regard to the spread of the disease, Dr. Kopp, of New York, said a consumptive in the early stages of the disease expectorates seven billion bacteria a day.

March 7 firc destroyed the Astoria Institute, Astoria, New York, a retreat for men suffering from alcoholism. The big building was isolated, and although the cntire fire department of the First Ward of Queens, two engines from Brooklyn, and a fircboat were summoned, the building burned down slowly, while the firemen could do little.

The fire burned so slowly that practically all the contents of the building were got out. All the patients left in order, and were driven in coaches to another near-by sanatorium.

John Stewart Kennedy, the president of the Board of Managers of the Presbyterian Hospital, New York City, is about to build and present to the hospital a modern and well-equipped home for its nurses. The building is to cost about three hundred thousand dollars, and will be located directly opposite the institution. It will be eight stories high, and is designed to contain a gymnasium, roof garden, and other accessories for the benefit of the nurses of the hospital.

Tre City Council of Cedar Rapids, Iowa, has donated a tract of land two hundred by three hundred feet, corner of B Avenue and Fifth Street, to the Sisters of Mercy, who will erect during the coming season a hospital to cost not less than fifty thousand dollars. Abraham Slimmer, the noted Waverly philanthropist, has agreed to give one dollar for every dollar raised in this city by the sisters up to fifty thousand dollars. Many liberal subscriptions are now in sight. 
MaIL advices reccived here from the Orient report that the hospital attached to the Tokyo, Japan, University was burned on January 29 and twenty-one patients werc burned and eleven nurscs and attendants were injured. It was a wooden structure, and there wcre ninety-six patients in it at the time of the fire, which burned from four to six A.M. The hospital was for the treatment of the cases of particular interest and had one hundred and fifty free beds.

The nurses of the Massachusetts Homœopathic Hospital TrainingSchool, Boston, have organized a Young Women's Christian Association. The society was formed October 12,1900 , and it now has a membership of twenty-six. It is felt that the association has been alld will be a help and inspiration to nurses, who as a class have so little opportunity to cultivate the spiritual side of life.

A NEW brick and brownstone hospital building, five stories in height, will bc erected in One-Hundred-and-Thirty-sixth Street, near Amsterdam Avenue, New York City, for the Hcbrew Benevolent and Orphan Asylum Society, at an estimated cost of seventy thousand dollars. The new hospital will be used for emergency purposes, and will occupy a plot one hundred by fifty fcet.

AT the town meeting in Brookline, Massachusetts, held March 27, an appropriation of eighty-six thousand five hundred dollars was unanimously voted for a new contagious hospital, with plans for early isolation of suspected cases, and comfortable quarters for those detained after the serious symptoms have passed till they can safely be permitted to mingle with well people.

A BILL was introduced in the New York Legislature to provide for the establishment of a hospital for the treatment of acute mental and nervous diseases in the city of New York, to cost not more than three million dollars, and appropriating two hundred and fifty thousand dollars for its maintenance.

The Presbyterian Hospital, Philadelphia, treated three hundred and twelve patients in the hospital and fifteen hundred and ninety-one persons in the dispensary during the month of February. The Board of Trustees havc created a department of laryngology and rhinology in the hospital and elected Dr. Arthur H. Cleaveland to take charge of it.

A sIX-sToRy brick sanatorium will be built on the forty by seventynine feet plot, Nos. 154-156 East Seventieth Street, New York City, by Annie R. Warren, of Dcerfield, Massachusetts, for the Mulhall-Warren 
Company. It will cost one hundred thousand dollars. It will be equipped with a complete gymnasium and a plunge bath.

Chardes A. Fellows has been awarded the contract for rebuilding Stormont Hospital, Stormont, Kansas. The portion which was destroyed by fire will be replaced on a more substantial plan than was adopted in the original building. The walls will be solid instead of veneered, and the size of the rooms will be somewhat enlarged.

ARciItects have been invited to present designs for the new hospital buildings of the German General Benevolent Society to be erected on the property bounded by Noe, Castro, Ridley, and Fourteenth Strcets, San Francisco. Over two hundred and fifty thousand dollars will be expended on the proposed improvements.

MIss L. L. DRown, superintendent of 'Training-School, City Hospital, Boston, is having a two-months' vacation, which she is spending in Southern California. Miss Mary M. Kiddle, "South Department," Boston City Hospital, takes Miss Drown's place while she is away.

Plans have been completed for a fifty-thousand dollar hospital at Oshkosh, Wisconsin, to be built in the business portion of the city. At the present time forty thousand dollars has been subscribed. The institution is to be operated by a stock company.

Miss Mosser, graduate of the University Hospital Training-School, Philadelphia, has been appointed superintendent of nurses at the MedicoChirurgical Hospital to take the place of Miss J. S. Cottle, resigned.

The graduates of the Central Maine General Hospital TrainingSchool have adopted a school-pin which is eliciting favorable comment. The school's motto is engraved on garlands hung on a pine-tree.

AN appropriation of forty-nine thousand seven hundred and fifty dollars has been granted for further construction of the Hospital for Insane Convicts at Dannemora, New York.

Miss Eleanor Ryan, who for two years was in charge of the Noble Hospital, Westfield, Massachusetts, has been appointed superintendent of Heaton Hospital, Montpelier, Vermont.

Mr. Thomas W. Lawson, of Boston, has given to two Boston charities, the West-End Nursery Hospital and the Crippled Children's Home, each five thousand dollars.

Miss Isaber McIsaAc, of Chicago, is taking a much-needed rest, and is staying with friends in Southern California. 